\title{
I Speak Tamazight, but in Arabic: Contesting the Cultural Terrain in Morocco
}

\author{
Khalid El Aref \\ Faculty of Letters and Humanities Dhar El Mehrez, Fez, Morocco \\ E-mail address: elarefkhalid@gmail.com
}

Keywords: Cultural translation; contestation; rewriting; Moroccan novel; canon; Amazigh; Arab

\begin{abstract}
The Moroccan novel, being part of the Arabic novel, is a very recent invention. However, in Morocco the novel has become an emblematic genre, which has known a momentous development. This article attempts a critical analysis of three recently published Arabic novels (Morocco) from a cultural studies perspective by highlighting the translational dimensions inherent in their writing, as well as their tendency to redirect attention to more urgent issues related to Moroccan identity.
\end{abstract}

\section{Introduction}

The first part of the title of this article-I speak Tamazight, but in Arabic--owes a great deal to the witty clairvoyance of Franz Kafka and Abdelfattah Kilito [1,2]. The second part is much more connected to my experience as a reader of the Moroccan (and the Arabic) novel. Both of Kafka's idea and Kilito's appropriation of it have a political thrust. In both cases, the mother tongue (or what stands for it) is hailed as the language that one speaks, or is brought to speak, even when one is speaking a foreign language; whence, the inherent tendency to translate the foreign language one speaks into one's mother tongue. The idea of translation pursued here as a guiding metaphor is not the act of rendering meaning from one language system to another; it is rather something deeper, where the act of writing is itself couched into a framework that does not question the act of translation while "rendering" an "authorless" text, conceived of broadly as a "fond", into a standard linguistic system. The "fond" is shared but indivisible. Identity is one such thing. This idea of "fond" might also be perceived in David M. Hart's summative formulation, "Scratch a Moroccan, Find a Berber." [3] While the idea of fond and all the concepts related to it, like fondement, fondation, profond, profondeur go back directly to Deleuze's insightful conceptualization and critique of the history of representation in western thought, the idea of translation which I have alluded to above seems to match perfectly the process of writing advanced here. In this context, the ideas of Octavio Paz are worth recalling.

Paz spoke about translation in relation to poetry. For him, writing uncovers some contradictions about the world. "The world," he says, "is presented to us as a collection of similarities" and at the same time it is revealed as "a growing heap of texts, each slightly different from the one that came before it." [4] The growing heap of texts is nothing more than "translations of translations of translations." [4] In other words, repetition is the governing principle of text production, an idea which Deleuze has applied to philosophical thinking. A logical deduction ensues: a text is at one and the same time original and a copy (in Paz's words, a translation). This is so because language, for Paz, is in essence a translation from the nonverbal world; it is something that is inherent to the very process of language learning [4]. Second, because "each sign and each phrase is a translation of another sign." [4] This seems to join Deleuze's argument that instances of disguise and displacement, together with their variations, go into the very formation of repetition; they are in Deleuze's words "the internal genetic elements of repetition itself, its integral and constituent parts" [5], which leads in turn to the assertion that "Difference is included in repetition by way of disguise and by the order of the symbol."[5] For Deleuze, the object is that which gets known and represented by its quality and extensity [6] 


\section{Methodology}

If these ideas get carried over into what is called, rather loosely, the Moroccan novel, they would allow for the possibility of coming out with a few remarks: 1- the Moroccan novel disguises itself in its masks: these might be taken to stand for the languages in which it is written (French, standard classical Arabic, Tamazight, Moroccan Arabic, Spanish), but also the themes repeated over and over throughout its short life. 2- What is commonly called Maghrebi literature was made to express the cultural "fond" of Morocco before the Arabic novel could afford to do so. Furthermore, this same Maghrebi literature (written in French) was generally qualified as a drama due to the issue of language. $[7,8,9]$ The modern Moroccan novel in Arabic, which is said to have begun with the

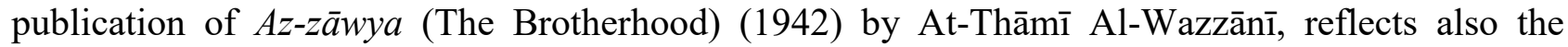
indecision contained in the idea of beginning, genealogy, or origin, depending on the ideological position of the critic, and might very probably restage the idea of drama following other terms.

Parrilla, for instance, argues that the Moroccan novel in Arabic can be traced back either to its emergence in the East, or to the Maghrebi novel written in French. [10] So, whether in Arabic or in French, the Moroccan novel seems to look elsewhere for recognition and legitimacy. What I have called "fond" emerges in diverse novels as that thing which is "shared" and "distributed" across idioms, languages, and ways of saying. But the "fond" can also reveal itself in a single work, say a novel here. In that case, the share of the "fond" has to negotiate its existence with a view to ensuring a place from where to speak. More often than not, because languages are never equal, this visibility is usually carved out in the space of the powerful. This can be seen in the process followed by minority/marginalized discourses, for instance.[11]

The mature novel in the Arab world was often equated with the realist novel in Egypt.[12] In Morocco, the novels of Abdelkarim Ghallab constituted a notable reflection of the mature realist Mahfuzian novel. Dafannā al-mā $\bar{d} \bar{\imath}$ (We buried the past) was particularly hailed as the mature novel in local criticism. Particularly with the publication of novels such as Al-ghurba (The banishment) and Al-Mar'ah wa'l wardah (The woman and the rose), Dafannā al-mā $\bar{l} \bar{l}$ came to be seen differently. For Parrilla, Al-ghurba (1971) by Abduallāh al-`Arwī (Laroui), and Al-mar'ah wa'lwardah (1972) by Muhammad Zafzāf (Mohammed Zafzaf) constituted a challenge to the "national" canon, represented by Ghallāb's "nationalist-realist" novel, We Buried the Past (Dafannā al-mā $\bar{d} \bar{l}$ ) (1966) [13] Ghallāb, who was a nationalist and one of the founders of the Istiqlal Party, wrote novels that celebrated the triumph of nationalist awakening, and represented a society in euphoria after political independence in 1956. Such a perspective was revealed to be reductionist both in its privileging of realism as the narrative strategy of representation and of nationalism as a unifying discourse. As Samah Selim argued, realism in the Arab world is different from its European counterpart because it does not imply representing what seems to go into reality on the basis of "simple verisimilitude"; rather, realism in the Arab world is a constructed "discourse about collective social and political identity."[14]

In 1970s, especially Marxian and structuralist criticism criticized We Buried the Past (Dafanna al-māạ $\bar{l}$ ) and uncovered its blind reliance on nationalism and realism. It is in this perspective that The Banishment (Al-ghurba) and The Woman and the Rose (Al-mar'ah wa'lwardah) represented a challenge to the Moroccan canon, according to Parrilla. By the narrative forms they adopted, these two novels "represented an attempt to overcome the traditional narrative modes embodied by Ghallāb, reflected in contents, characters and language, as well as in the banishment of the single omniscient narrator." [15] Later, other novelists like Muḥammad Barrāda (Mohammed Berrada) carried the limits of experimentation in the novel genre to its extremes. In The Game of Forgetting (Lu'bat an-Nisyān), for instance, the history of Moroccan nationalism is no more the one issue that is at stake. When it is mentioned, it is wrapped up in a plot where different, sometimes contradictory and conflicting perspectives are brought to the fore, usually with gender, ideology, and sub-cultures playing the role of a crucial determinant of the characters' worldviews.

The technique of multiple narrators, while ensuring objectivity and relative reliability, inserts the possibility of doubting a unique and a unifying truth. Even "the narrator of narrators", a formalistic device employed by the author, seems to be doubtful sometimes about the authenticity 
of some of his own accounts and interpretations. In Magda Al-Nowaihi's terms, The Game of Forgetting (Lu'bat an-Nisyān) reflects "the tension between the need to retain history on the one hand, and to liberate oneself from the past on the other."[16] These tensions give way to contradictions that are assumed and then grappled with in an attempt to be explained away while keeping in mind that there is no comfortable truth beyond the mere fact of playing with language and memory. In essence, The Game of Forgetting is played out as an orchestration and dramatization of two contradictory visions about the past and memory, represented by Al-Hādī, the main character, and At-Țāya ${ }^{\varsigma}$, his elder brother. While Al-Hādī complicates life and celebrates the body, turning thus the future into a promising liberator, Taya ${ }^{\varsigma}$ seems to have buried the past.

In this article, I argue that a new generation of novelists has carried with this trend of experimentation with form, while giving yet another turn to the identity politics that the Arabic (and Moroccan) novel is taken to represent, contesting the cultural terrain of Morocco. The main difference, however, between The Game of Forgetting and the novels at hand lies in the fact that identity and memory are taken up in relation to other components of Moroccan identity, like the Amazigh and the Jews. In the Moroccan context identity politics centered around issues of Arabness and pan-Arab ideology almost exclusively. In general terms, the trend that the Arabic novel in Morocco has followed in the very recent years can be perceived in two terms, both related to identity, while at the same time holding different positions as to what identity really means. This trend is in line with the idea of Tradition (Thurāt), which strongly emerged with Muhammad ${ }^{\complement} \bar{A}$ bid Al-Jābirī (1935-2010). This first trend relates to what I like to call the neo-pan-Arab revival and questioning.

Thematically speaking, the novels included under this heading pay close attention to a reimagined Arab past, where Andalusia is approached as an idyllic image, a metaphor that is brought to bear on the present. Under this rubric, one might include Hāda al- 'andalusī (by Binsālim Himmīch), translated as A Muslim Suicide (2011) by Roger Allen; Al-Müriskī [The Morisco] (2010) (by Hasan 'Awrīd), and almost all the novels by Abdual 'illah Bin'arafa, except for Yāsīn, qalb alkhilāfa (2013) [Yasin, Heart of the Caliphate] and Tawāsìn al-ghazzālì (2011) [Al-Ghazzali's Tawasins]. The second rubric might be termed the nation-state narratives.

The novels under this rubric address the issue of the nation-state in a number of aspects. Whether seen as a diatribe against the rule of Hassan II ('Ulbat al-'asma ' (2014) [The box of names] by Muhammad Al-'Ash`arī; Qițun 'abyadun jamīlun yasīru ma`̄ī (2011) [A Beautiful White Cat is Walking by my Side] and Țā'irun 'azraqun nādirun yuhalliqu må $\bar{\imath}$ (2013) [A Rare Blue Bird is flying by my Side] by Yūsuf Fāḍil; bāìdan mina aḍ-dawḍā' qarīban mina as-sukāt (2014) [Far from clamour, close to silence] by Muhammad Barrāda;), or as an attempt to redress the imbalances and exactions of the post-independence state that culminated in disillusionment, (fitnatu ar-ru'üs wa an-niswah (2000) [The spell of heads and women], Mihanu al-fatāh zayn chämah (1993), [The tribulations of the young man called Zayn Chama], Mu'addibati (2010), translated as My Torturess by Roger Allen, all by Binsālim Himmīch), all of these novels approach the identity politics issue from an incipient Arab perspective.

The three novels that I propose to discuss in this article all deal with the identity politics from an internal perspective by stressing the Amazigh component, together with other components, in the Moroccan identity. They constitute a literary reply to the political, social, and cultural debate that started in Morocco a few years ago, which was initiated by the political movement of February 20 that resulted in drastic changes in Morocco's political arena.

This article attempts to look at three Moroccan novels with these ideas in mind, laying stress on the way hyphenated as well as purist identities take center stage in places that get redefined and re-imagined. These three novels, each in its own specific way, question the idea of Moroccanness as being based exclusively on an Arab-Muslim dimension. In relation to Numedia, [17] I discuss how the narrative revives, reconstructs and encodes a symbolic idea of a re-imagined Amazigh nation and swiftly discards it mainly through the "killing" of Murād-'Awdād and the disappearance of Numedia, the mythical dumb girl, within a context characterized by what I would like to call competing identities in a memory caught in lament over love and place. 
The parallel created and maintained between Murād-'Awdād and Mustaphā Sa'̄ìd (as will be developed later) operates in terms of identity politics in two conflicting, yet perplexingly complementary ways. The symbol of sexual prowess is relocated and appropriated by an Amazigh character, only to give way to an inherent disavowal of the Arabic context where it initially emerged. 'Awdād dies because he cannot manage his identity as both an "Amazigh" and an "Arab". $\mathrm{He}$ is an Amazigh who dies tragically as a Moroccan in both an Arab and an Arabic context. With respect to Pike Fishing Season [18], I attempt to show how the lake, a powerful symbol of Amazighness, becomes both a mythical and dangerous place refiguring Amazigh identity both from within and from without. In connection with Sodom (Sadüm) [19], I explore how the novel attempts a deconstruction of what it is to be Moroccan, an exercise the narrative carries out by bringing about diverse, often conflicting, facets of Moroccan identity, all of which filtered through a politicized vision that celebrates the body as a means of resistance to different forms of power.

The novels at hand were all published in 2014 and 2015. 'Ismā̄îl Ghazālī published Pike Fishing Season (Mawsim sayd az-zanjür) in 2014. The novel featured in the long list of the 2015 International Prize for Arabic Fiction. Both Sodom and Numedia were published in 2015, the latter featured in the short list of the 2016 International Prize for Arabic Fiction. The trio of novelists attempts to render the complex reality which the narrators and the characters have to grapple with. However, unlike in The Game of Forgetting, for instance, these novels use experimentation with form to give validity to a component of Moroccan identity: Amazighness.

Numedia and Pike Fishing Season tend to approach reality through myth while Sodom attempts a deconstruction of the different forms of national belonging. The authors belong to different generations. Two of them are secondary school teachers while the third works in the media industry. Tarik Bekkari was born in 1988; he lives and teaches in Marrakech. Numedia is his debut novel. Ismail Ghazali was born in 1977 in Mrirt, a small town in the vicinity of Khenifra in the heart of the Atlas region. To date he has published three novellas and six collections of short stories. Pike Fishing Season is his first piece of long fiction. 'Abdalhamīd Shawqī was born in 1960. He teaches philosophy in secondary school. To date he has published a collection of poems. Sodom is his fourth novel.

\section{Discussion}

After having spent twenty-five years in France, Murād al-wa`l returns to his homeland, accompanied by Julia, his French lover. He buys a hotel in Ighrem (Ighrm), a small village in the Atlas Mountains, and retreats there. With his return, everything that had been so far repressed or forgotten takes center stage: he finds himself caught between the past and the present. The past is revived through his painful memories associated with Khawla, who committed suicide after he had left her while she was pregnant; his life story with his adoptive mother, who used to torture him when he lived in Ighrem, leaving indelible marks on his body; and his short love affair with Niḍāl during university years.

Soon it turns out that Murād-'Awdād is still suffering from a psychological stroke incurred after Khawla had committed suicide, and is being treated by a psychoanalyst called Binhāchim. Julia, a writer in dire need of inspiration, had turned to Binhāchim for help. In return for money, the latter had provided her with Murād's medical record, which she was using as a basis for writing a novel about Morocco, taking Murād as a live model. Murād uncovers the farce and finds refuge in a dumb Amazigh girl called Numedia, whom he falls desperately and passionately in love with. The narrative ends with the death of Murād-'Awdād and the disappearance of Numedia.

The narrative develops relying on two movements: the first one, moving forward in time, focuses on 'Awdād's relationship with Julia and the real life of the people in Ighrem. Both 'Awdād and Julia are seen as strangers by the locals. This forward movement of the narrative culminates in 'Awdād's encounter with Numedia. The second movement, turned toward the past, relates to 'Awdād's memory. Wherever he goes, he is pervaded by reminiscences of his past life, reminiscences that he keeps mostly for himself, until he meets Numedia with whom he shares his 
most secret sorrows. His love for Khawla and her suicide are also part of this movement toward the past, as 'Awdād never lets go of her diary, which he happened to get somehow after her death.

The anti-colonial stand of the novel (condemnation of Julia's manipulative moves as well as the role of the local elite collusive with colonialism and its discourse, Binhāchim) is in line with the critique leveled on colonialism by figures such as Frantz Fanon, Albert Memmi, Jean-Paul Sartre, and Edward Said). The love story between 'Awdād and Julia is one aspect of this relationship, while the story of the mysterious colon and the resistant Sīdi 'îsā is another aspect. However, in its address of the colonial issue the novel takes up only the part that is related to representation, turning a blind eye to the material conditions that sustained and invigorated the strong hold of imperial powers on colonized countries.

These material conditions are relocated (and thus probably subsumed) within the spatial metaphor of centre and margin, since the whole work celebrates Ighrem as both a curse and a spectacular liberating dream. In this respect, Binhāchim, being a symbol of the powerful elite, is represented as a cupid person who is avid for money. The "Ben" attached to many family names in Morocco is socially and politically charged; it usually coincides with high-rank Fassi families that constituted a powerful social and political elite throughout the recent history of Morocco. [20] In this perspective, Binhāchim is representative of a whole rotten portion of Moroccan society. In addition, the prefix stands in sharp contrast to "Āit," the Amazigh prefix attached to the names of Amazigh families, among which the Āit Marghād, Numedia's nomadic tribe.

The main thrust of Numedia resides in its attempt to foreground Amazigh identity through the representation of Ighrem as a marginalized space and Numedia as both a curse and a cure. This attempt is framed within the oft-represented encounter between the East and the West, which takes form in Numedia through the love story between Murād-'Awdād and Julia. In this sense, Murād'Awdād seems to be another copy of Mustaphā Sa'īd in Tayib Sālih's (Tayeb Saleh) celebrated novel Season of Migration to the North (Mawsim al-hijra ila al-shamāl) (1966).

Both Mustaphā Sa'īid and 'Awdād conceive of the encounter between the East and the West in terms of clash, conflict, and misunderstanding. In addition, both characters are approached in a mythical way. For Julia, 'Awdād is a myth, too[17], exactly in the same way Mustaphā $\operatorname{Sa}^{\varphi^{\top}} \bar{d}$ was represented. One of the main differences between Murād-'Awdād and Mustaphā Sa'̄̄êd, however, lies in the way the return is dramatized by focusing on the protagonist's native town. In addition, while Season of Migration to the North is narrated by a local narrator from the village, much of the narrative in Numedia is undertaken by Murād-' Awdād, who narrates his own story using the firstperson singular, and Julia's voice as refracted in the draft of her novel about Murād-' Awdād.

In Season of Migration to the North again, the story focuses much more on Mustaphā Sa'īd's encounter with English women in London in a long series of flashbacks, whereas Numedia stages the return of Murād with Julia in Ighrem, disregarding Murād's life in France, making it possible to retrieve the memory of the locals. Furthermore, for Mustaphā Sa'īd, sex is a kind of weapon that he used to avenge himself from the West; Murād does back up the idea of sex, without pushing the idea of revenge to its extreme. After having sex with Julia, Murād tells her: "Sex is the only real alternative to all the failed love stories...love is a sublime force of destruction, while sex is a base form of construction." [17] Elsewhere in the novel, Murād states: "Sex is an animal that rests inside me; it violently moves me into deflowering the realm of flesh of my victims." [17] About him, Julia says: "Murād is exceptional in terms of sex...I have never had even a quarter of the pleasure (I had) with other men, including my husband.’[17] Thus, like Mustaphā Sa'īd, Murād possesses sexual prowess.

Another important aspect relates to the implications underpinning the very act of writing. In Numedia, Murād is countering the misconceptions and the distorted images of him that Julia holds. In an aside, Murād says: "these papers do not reflect who I really am or who I really was...They are about another Murād who exists only in Benhāchem's mind." [17] In another context, he addresses Julia by saying: "I think that you cannot write me properly, unless you manage to infiltrate into my veins."'[17] Yet again, 'Awdād reiterates the idea of the impossibility of knowing the other. Even if Julia manages to write about 'Awdād, she would only "write" her "own atrocities," with her 
“failures superimposed on his ['Awdād's]"[17] This reflects perhaps the ambivalent feelings of love and hate/fascination-repugnance that has characterized the relationship between male men from the East and female Westerners.[21] The failure of the encounter between 'Awdād and Julia is indicative of the Eastern protagonist's self-reconciliation and rejection of the Western other in Arabic fiction. The protagonist usually ends up retaining his cultural identity, a pattern which El Enany elevates to the status of a "norm." [21]

Like Mustaphā Sa`̄ìd, 'Awdād is also into relationships with more than one woman. All of them have a liking for writing and are writers in a sense. Before committing suicide, Khawla had written her diary and made sure that it would reach 'Awdād. While taking a look at the diary every now and then, Murad-' Awdād finds himself constantly opining over the loss of Khawla. At a certain moment, Niḍāl, to whom he had been drawn during his university days in Fes, reappears again. Niḍāl likes poetry and has published a few free verse poems dedicated to 'Awdād.

What is important about these two women is the fact that each one of them represents a mode of writing in the Arabic tradition. Khawla is always invoked in relation to classical Arabic poetry. In her diary, she quotes the famous Arab poet 'Imru'u al-qays [17] while Niḍal is a modern poet, more in line with post-Nahda figures like 'Adūnīs and 'As-Sayyāb. Thus, Khawla's suicide symbolically points to a dying Arabic tradition of classical verse writing. At the level of the narrative, however, the idea of al-'atlāl, a poetic convention that dates back to the classical preIslamic poetry, is relocated in relation to Ighrem, although 'Awdād knew Khawla elsewhere.

Thus, the whole novel seems as if it were an orchestration of the mourning over the death of Khawla. As for Murād, he seems to be the poet par excellence, for in the many epigraphs present in the novel, his words are put side by side with quotations from Nietzsche, Marquez, Shakespeare, among others. In the final analysis, Murād tragically dies at the end because he cannot successfully manage the competition of the different identity modes at play inside him. Following in the footsteps of the younger 'Awdād, who had wanted to commit suicide at an early age due to his situation as a parentless child, the grown-up 'Awdād dies while trying to meet Numedia, the mythical dream woman. While walking he cannot rid himself of the guilt he had been experiencing since he learnt about Khawla's suicide. All alone he addresses Numedia in these terms: "Numedia, haven't you met in the back mountain passes with a beauty called Khawla? I'll look for her, I'll do it. I have spent much time looking for her amongst the living. It is high time I found her amongst the dead." [17]

Beth Baron neatly summarized the relationship between the idea of nation and national narratives. According to her, "Nationalist narratives generally identify an external enemy, heroes, a vanguard party, and pivotal moments." [22] This is the case, for instance, of Kateb Yacine's Nedjma (1956), which was hailed as a national narrative. Numedia can be approached in a similar way in relation to Amazigh national identity, notwithstanding the absence of a vanguard party. In fact, all the other components noted by Baron are present in Numedia: there is an external enemy (Julia, the ex-colonizer and the Muslim radicals), a hero (though tragic; I will discuss later why he should only be conceived of as a tragic hero), and a pivotal moment (2003, the year when terror struck in Casablanca). These narrative elements are reshuffled to revive a mythical dream/vision of an Amazigh nation, only to swiftly dispose of it.

Numedia, the dumb beautiful nomad girl, makes her entry into the narrative only in the second half of the novel after 'Awdād has uncovered Julia's farce and long after the reader has learnt about Khawla's suicide. Numedia is represented in mythical terms: she is a queen, an angel, and more crucially she is the savior of 'Awdād and a cure for his ills [17] For the locals, however, Numedia does not exist, or rather she is "the spirit of the river" [17]. In addition, Numedia and Ighrem are almost synonymous. When she is introduced into the narrative, the invocation of Ighrem becomes scantier, which may mean that they represent almost the same thing. The invocation of Numedia happens at a moment when the reliability of 'Awdād is weakened.

In fact, his hallucinations as to the existence of a mysterious group of long-bearded terrorists who are intent on killing him, are revealed to be unfounded. In addition, outside Murād-'Awdād's version, there is no narrative evidence that Numedia was seen or encountered by any of the other 
characters. In other words, at one level, she is a figment of 'Awdād's deranged consciousness. At another level, she is real because she possesses discursive materiality in the narrative (she is described, put in a time-space frame, and given a human dimension). Furthermore, Numedia is always invoked in a context where Khawla's memory and the Muslim radicals are present, either through juxtaposition or through free association.

The first instance of Numedia's entry into the narrative occurs in book two, chapter 7 . The encounter is highly symbolic, and is couched in a dreamlike atmosphere. 'Awdād, who is certain to be assassinated by the Islamists, goes to a nearby spring in bold challenge of his enemies. It is there that he has the first glimpse of Numedia on horseback. The moment of the encounter is described in these terms: "At at moment and the moments after it, I felt I was experiencing a dream, which was exactly the feeling that used to repeatedly pervade me while I was asleep. That same feeling secretly signified to me that the issue was but a dream." [17] Numedia in turn is described in these romantic terms, an almost idyllic figure: "...her thick black hair sprawled on her black dress, fluttering and spreading out in the mild breeze...her diamond-like neck was a token of beauty when she looked up, her dainty little nose proudly high." [17] Most importantly, however, is the idea that she represents an antidote and an alternative to Islamic radicalism, whose representative characters are called "the neo-Barbarians."

The allegorical figuration of Numedia can also be perceived in the narrative's tendency to reverse the order of things in relation to the present and the past. Here I turn to Renan's celebrated article for a crucial detail; according to him, the nation is a spiritual idea based on a common legacy of memories and present-day consent of its members (these two ideas constitute one single idea, according to Renan).[23] If the nation is to continue existing, its members are supposed to "perpetuate the value of the heritage." [23] It seems that Numedia does just the opposite, both at the level of its address of time and the symbols that stand for the other components of Morocco's identity.

The first reversal that the narrative operates relates to the relationship between the past and the present. In a novel that symbolically goes back as far as the Greek and Roman eras to represent Amazigh identity, it is expected that a far-arching memory will be dealt with. In fact, memory is present, but it is just the recent memory (understood as remembrances or reminiscences) of the tragic protagonist, showing perhaps discreet (but sure) signs of un-consent. Conversely, Numedia is associated with the present both in the narrative and as a metaphor of the novel. Although she might be only a utopian dream that only 'Awdād is experiencing, she is attached to a real tribe in the narrative fabric. This gives her both interiority and materiality. Numedia only fully realizes the nationalist aspiration in 'Awdād's imagination. For him, she is both a truth and a myth, which is what the idea of the nation is all about.

Furthermore, the romantic portrayal of Numedia involves both displacement and sublimation. The fact that she is portrayed through a dream/delusion can be explained in terms of what Jacques Rancière calls "the distribution of the sensible", defined as "the system of self-evident facts of sense perception that simultaneously discloses the existence of something in common and the delimitations that define the respective parts and positions within it. A distribution of the sensible...establishes at one and the same time something common that is shared and exclusive parts." [24] This system is deployed in writing where almost everything is played out; it is the novelistic world, in a sense, which is "the factory of the sensible" [24] More particularly, subjectivization, which is "the process by which a political subject extracts itself from the dominant categories of identification and classification" [24], operative in the novel through "counter exclusion," [11] culminates in a cul-de-sac. There is no Numedia outside the mind of 'Awdād.

The portrayal of Numedia as a dream might also be interpreted as an effect of the real for 'Awdād. She is there because there is no need for her to manifest herself, a covert idea that structures his emotions; she uncovers herself only to those who invoke her as a dream, namely those who cannot reconcile the competing elements of Moroccan identity in themselves. In Numedia, Numedia as a woman-nation cannot have been revealed in a different mode other than that of dream/delusion because the police order (in Rancière's sense) operative in the realist configuration 
of the novel precludes its development as a Nation. A nation exists as a myth; it exists also as a dream.

Pike Fishing Season relates the story of a Franco-Moroccan man born in France to a FrancoMoroccan couple. He returns to Morocco on the advice of a Moroccan singer whom he meets in France during a concert organized there. He retreats to Aguelmam Azegza, a far-off lake in the heart of the Atlas Mountains and waits for the singer to show up. She only shows up a little late. In his retreat, he delves into his memories and recalls a French friend of his who had committed suicide shortly after she had finished writing a mysterious novel entitled "The piano, the preferred home of the pike." This French friend's novel constitutes part of the novel that Pike Fishing Season is.

The return of the protagonist is also an attempt to learn about the place where his mother had lived the larger part of her life before she died in France while giving birth to him. The narrator is also in search of the grave of his mother, buried in her native village. In the hotel and the nearby lake, he meets with a score of characters, among whom an Englishwoman and her American husband as well as a twenty-year-old Moroccan young man who works at the hotel. In his retreat the narrator learns about a web of intersecting stories of people, both Moroccan and non-Moroccan, who lived near the lake or passed by it, and some of whom died there. The lake is represented as an eerie place where characters from different cultural backgrounds and countries meet. They seem all to be in search of something mysterious that links them to the lake.

As the intertwined stories unfold, the history of the lake unfolds in an atmosphere enveloped in uncanny, phantasmagoric flights and scenes, knitted together by labyrinthine quests for meaning and symbolic retrievals of past incidents in the hotel and stories of death, sequestration, and rape in the area around it. These labyrinthine quests are almost always built on a string of coincidences that reduce the divide between reality and fiction to the extent that Aguelmam Azegza (and its environs) seems to be the real protagonist of the novel, an essentially dangerous one. But this danger is much more directed to foreigners than to the local inhabitants. In a conversation with the twenty-year-old man, the narrator learns that "stones are aimed at foreigners" [18] and that the "tragic lovers of the lake" drowned in it. [18] Such a representation of the lake and its surroundings seems to suggest a supposed intransigence of Amazigh identity throughout its long history.

Furthermore, the different stories "written" by the different characters constitute a very long prelude to the actual story of the main narrator's discovery of his origins, and more particularly the retrieval of the ordeal of the "lake girl", the narrator's mother. This retrieval is strongly built on a series of visions that verge on delusion and highlight the uncanny. The realist description and explanation of the minutiae of the narrator's story found in the end of the novel serves as a means of dissolving the anxiety of the impossibility of knowing the reality "out there" into the more secure sense of belonging to a family and a lineage. Ironically, this symbolic recovery of the sense of belonging is also an instance of loss, as the narrator's process of reconnecting with his Amazigh family members is reached through locating the grave of his dead mother, who had been buried as she had wished in her native village.

The characteristically episodic manner in which the narrative is constructed is operative both at the level of a decentered locus of writing and in the aesthetic sublimation of the lake. The narrative of the acculturated Moroccan-French narrator hands the reader over to a series of narrators who in turn attempt to retell the story of the lake (and/or the stories of people living near it) from his or her own perspective. No sooner the link is established between the string of events than the narrative proceeds to undo them, embarking upon a "new" story that is once again linked in a fantastic way to another aspect of another story.

The disjointed aspect of the narrative reveals the difficulty of approaching Amazighness in a straightforward manner. It also underscores the perplexity of knowing in any certain way the distinctive features of Amazigh identity. The part entitled "The seven stories of the lake" captures part of I want to say. These stories are told by an ambivalent narrator. He seems to know perfectly the history of the lake, but at the same time the stories themselves constitute a narrative reconstruction of the tourists' photographs hung in the hotel lounge. These sections of the narrative 
recount the stories of a number of non-Moroccans (some of whom meet their death) who have been to the lake: an Italian painter, a Swedish film-maker, a Japanese fisherman, the wife of a mysterious British general, a Russian poet, a German violinist, and finally the girl which the novel calls "the lake girl." The latter story, which is the main focus of the novel, is thus framed (and probably drowned) in a web of stories whose protagonists come from different parts of the world. The lake is thus re-imagined from without. This only confirms the main narrator's initial claim that Amazigh identity is part of the Mediterranean [18]

The lake is also a fascinating place. It is a location where all types of artists turn to in search of inspiration. Famous actors, film-makers, novelists, script-writers, among others, have all been to the lake. The lake becomes a gathering point, but it is one that is revealed in its fullness only diachronically through the memory of the place in what seems to be a symbolic interpretation of the vestiges of the lives that once populated the lake. The fictional realistic atmosphere in which the lake is bathed is made up of a multi-tiered microcosm that becomes sundered as the narrative unfolds, reflecting not just the impossibility of capturing Amazigh identity in a champion metaphor, but also the difficulty of coming to terms with the act of writing and the convoluted texture of the truth it aims to convey.

In fact, with the entry of each narrator the world of the lake takes on new mythical and phantasmagoric dimensions that add up to its already eerie aspect. A particular tale is at one and the same time approached according to different genres; as a short story being written by some unnamed mysterious writer, as a film script being finalized, and as a novella being written by yet another unnamed mysterious novelist, as a diary of a twenty-year-old man, which another character wants to turn into a book. This technique brings together many genres in a game in which each one parodies the other. Only in the fourth part of the novel does the narrative get back to the initial Franco-Moroccan narrator's journey of discovery whose recovered story comes full circle only through texts written by others.

Pike Fishing Season attempts to give voice to Amazigh identity by making all characters and events revolve around the lake of Aguelmam Azegza. While the postmodernist stand of the novel can be perceived in the insistence on the near impossibility to know who writes what and to whom, the modernist side of the novel can be seen in the way the lake itself is represented as both a dangerous and fascinating place by relying heavily on repetition of scenes and events from different perspectives. Some of these scenes and events stand out as figurations of the uncanny, understood here as a form of intellectual uncertainty that results in an acute sense of concealment. In addition, the uncanny is used to create a sense of impending danger that is attached to the lake. The novel is replete with figurations of the uncanny; the following passage particularly reveals how the FrancoMoroccan narrator makes sense of "reality":

In the eyes of the forty-year-old woman there is something that betokens an unknown region inside me, and in the emerald voice of the little girl there is something that dusts off the stars in a forgotten place in my memory; and in the squeaking sound of the boy's handmade violin there is something that disinters my being, and in the perseverance of the near sixty-year-old man there is something that corroborates my idea of the glorification of the perplexity of the human being. [18]

The narrator approaches his surrounding as though it were part of his personal identity. In addition, elsewhere in the narrative he thinks that he knows the characters, but he is never certain. His intellectual uncertainty and the resultant anxiety pervade the whole narrative. The narrator cannot interact with reality unaided, not so much because he has lived far from it for a long time but mainly because it stands concealed from him. This state of concealment validates the narrator's dire need of a "guide" [18].

The "guide" proves to be the narrator's reading of the different manuscripts that he happened to get hold of. Commenting on "the road to Azouggar" manuscript, the narrator says: "I finished reading 'the road to Azouggar' manuscript completely bewildered and internally falling apart as a consequence of unsettling questions: how can this story, script, or novel be at one and the same time 
fictional and real?" [18] A few pages ahead, the answer is provided: the local characters mentioned in the different stories are the members of the narrator's family.

The narrator affirms that their "weird souls never left the place, and they constituted themselves to me in the visions whose very nebulous phases I had lived." [18] The author's inability to know in any authentic way the characters and their reality is also reflected in the near absence of names. The characters that have names are scant: Virginia, Hues, Aziza, Shāmah, Nawwār. Even the Franco-Moroccan narrator does not have a name. The remaining characters, which constitute the majority, are identified by what they do or by their physical aspect, or else by their age. Thus, characters are called "the fair-haired girl," the "blond fisherman," the "lake girl", the "violinist", etc.

This aspect of the novel reveals both its dystopian side and the inability to know the reality "out there." However, the only Amazigh character with a name is Shāmah, used sparingly and for which the more romantic identification "lake girl" is preferred. Ironically, Shāmah, meaning beauty spot and/or mole, is an Arabic name. This could be interpreted as a claim to the hybrid nature of the Amazigh identity for which Shāmah stands symbolically.

In a related vein, the narrator's ultimate identity is not revealed through his name, but rather through lineage: Shāmah, the "lake girl" who had been through trying ordeals before she came to be delivered by a Frenchman who married her and took her with him to France, where she gave birth to the narrator, is the narrator's mother. A happy ending, but not quite. This is so because the narrative starts off with the mother already dead. The uncanny is thus dissolved into the realistic reconfiguration of the narrator's story: the narrator "recovers" his "roots" and by the same token reaches the point which allows him to "mourn" his dead mother, as he eventually comes to weep at her grave. [18]

Unlike the two novels discussed above, which pursue a construction of Amazigh identity in a somewhat romantic and utopian way, Sodom proceeds to deconstruct the category of identity in diverse ways. The technique followed in the construction of the narrative reveals the different facets of Moroccan identity. Unlike Numedia and Pike Fishing Season, which rely on myth and romantic representation as well as on narrative "counter-exclusion" to lay claim to Amazigh identity, Sodom posits the politics of the body as a way of resisting power in its diverse aspects, constituting thus a sharp reply to the proponents of "clean art", and a problematization of Moroccan identity. This new form of resistance to power is applied to all the different components of Moroccan identity.

Sodom relates the intertwined stories of seven characters: Camelia, 'Āslīn, Sāmia, Aḥlām, Mīlād, Nūrī, and Ar-Rāheb. The characters come from different cultural and social backgrounds. Camelia, a painter, lives in Rabat and has studied at the French Lycée; she represents the acculturated part of Morocco's population. While she was still in secondary school, she fell in love with Ezrā Hāyīm, a Moroccan Jew living in the same city, and becomes pregnant. Her parents decide that she abort because they can't stand the fact that their Muslim daughter gives birth to a baby from a Jewish father. As the story unfolds, it turns out that Camelia herself is not the born daughter of her parents. In fact, they had adopted her after her real parents - a Jewish coupleentrusted the father with the baby and vanished.

As for 'Āslīn, who has chosen to become an actress as a way of liberating her body, is an Amazigh young lady; she has studied at Lycée Tariq in Azrou and moved to Rabat. Through 'Āslīn, the novel recollects the colonial period in Morocco and how the ethnographic discourse came to produce truths about the Amazigh history in far-off places. 'Āslīn is caught between her Amazigh roots and what she considers to be a repressive cultural politics administered by the postcolonial state.

Sāmia, a poet and a single mother of a young girl called Nabila, resembles 'Āslīn. She, too, professes writing with the body as a way of emancipation. Her daughter is the fruit of a short-lived affair during her school years with a young Arabic teacher called Halīm Tayhān. Later, she succeeds in reconciling with the begetter of her daughter, whom she had loathed for being conservative. Aḥlām, a radio journalist by profession, also fell in love with Kamāl and Ismā'îl 
during her early adolescence. She later reconnects with Kamāl, who returns to Morocco after having lived in France with his family.

Ar-Rāheb, a cynical novelist, epitomizes the response of the angry, disillusioned intellectual. $\mathrm{He}$, too, is into diverse sexual affairs with Sāmia and 'Āslīn. Nūrī, a filmmaker who had studied in France, returns to Morocco with ambitious innovative projects, and is into sexual affairs with 'Āslīn. Mīlād, a sensitive poet associated by Sāmia with the renowned poet Al-Hassan Ibn Hāni', better known as Abu Nawwās, belongs to a modest social class. His story is a recovery of the memory of an impotent father imprisoned after the assassination of Zina, the rebellious and promiscuous mother. The development of Mīlād's story, which unfolds through Sāmia's reading of Mīlād's memoirs, reveals that the father had confessed to killing the mother to protect Mìlād, who turns out to be the real killer of Zīna, his own mother.

The novel is made up of twenty-one chapters narrated by the seven narrators-protagonists. Each one of the protagonists narrates three chapters following a turn-taking principle. In terms of sheer form, the technique reflects a "democratic", gender-bias-free distribution of the right to speak. In addition, the novel seems to cater to a gender-based "positive discrimination" as the number of female narrators-protagonists is relatively higher.

The title of the novel is more in line with Nūrī's perspective, as it is he who makes explicit use of the word "Sodom" and appropriates it. The multiplicity of perspectives and world views strongly recalls the narrative technique in The Game of forgetting. However, while the narrative world in the latter work is mastered and policed by the narrator of narrators, who is in command of the development and orchestration of the other characters' memories and world views, Sodom is devoid of this mediating stance, as the protagonists-narrators are revealed directly through their own words as well as through the eyes of the other characters. The ensuing interplay between the characters and their different worldviews maintains a tone of multiplicity and positive constructive interaction.

In this perspective, Sodom seems to be a challenge of The Game of Forgetting in both form and content. Formally, the technique of the dominant stance of the narrator of narrators is banished. This formalistic technique is indicative of a will to power, at least in the parallel between its linguistic form, i.e. rāwī ar-ruwwāt (the narrator of narrators) and the linguistic form of qādī alquddāt (lit: the judge of judges), the head Muslim judge and administrator of punishment, who is also responsible for other judges. In terms of content, Sodom shifts the focus from the era of nationalist resistance, present in varying degrees in both We Buried the Past and The Game of Forgetting, to the more virulent movement of February 20, which constitutes the socio-political basis of the novel at large.

Many characters in Sodom are concerned about the issue of writing and its possible meanings and nature, but two of them stand out: Mīlād and Ar-Rāheb. Mīlād, for instance, thinks that becoming a poet has nothing to do with "inspiration, morals, and human ideals"; in his case, "it was a result of a criminal act."[19] Mīlād is not only alluding to the act of having killed his mother, but also laying claim to a new sensibility about writing. Also, writing, for Mīlād, is likened to a sexual act where the text produced is similar to an orgasm. That's why he is against a certain type of writing that hails morals; he states that "all poets whose writings are motivated by civilized morality are bad poets." [19] Writing becomes an act of subversion of morality.

Likewise, Ar- Rāheb, who is also a novelist, aligns himself with a type of writing grounded in subversion and the celebration of the body. When he was in secondary school, he wrote a story about a young man whose mother dies. Instead of burying her, he leaves her body in the house and communicates with the body as though nothing has happened. When Ar-Rāheb gave the story to his Arabic teacher, the latter was angered and threw the paper on the floor, saying: "what's this 'shit'? You foundling, do you think that my pen is to be besmirched by this monstrosity? Get out and don't come back until you have written a summary of Jil ad-dama", which is part of the syllabus" [19] It is clear that Ar-Rāheb and his Arabic teacher hold different views about writing and its nature. For the latter, writing is more in line with moral exhortations and sermons that appeared in the writings of "Jurjī Zaydān, Al-Manfaluti, and Aḥmad `Ali Bakatir." [19] 
The teacher does not only refuse Ar-Rāheb's short story, but he points out to him what is considered to be the true literature. For Ar-Rāheb, however, Jīl ad-dama' (Thirst Generation), a novel written by Mụ̣ammad 'Azīz Laḥbābī, is "a ridiculous novel." [19] Ar-Rāheb is also disappointed by the Arabic novel, which he does not find to his liking because it does not mention the body. Ar-Rāheb expresses his views in these words: "The novel is a real act of love-making. Most of the Arabic novels are but a world of courteous morals; they resemble an adolescent who tells his parents: I want to get married according to the Sunnah of God and His Prophet, instead of telling them the truth: I want to sleep with a woman to get pleasure." [19]

This does not mean, however, that Ar-Rāheb debunks all Arabic novels. In fact, it seems that he advocates writing with the body, that's why he raises Mohammed Choukri's writings, especially For Bread Alone above all others. During a discussion on writing and art, he concludes: "Mohammed Choukri was a child who got rid of the whip and let his body narrate with complete freedom." [19] Furthermore, the novel genre is seen by Ar-Rāheb as an "act of sexual intercourse." [19] By highlighting the erotic side of writing, the novel seems to stand out as a challenge to the moralistic vision that the Arabic novel is allegedly supposed to vehicle. Writing, Sodom suggests, is inseparable from the politics of the body.

So unlike Numedia, which revisits the theme of the East-West encounter through the (fake) love-story between 'Awdād and Julia, Sodom sets the tone for a different type of writing and for new themes, which all culminate in viewing identity from the perspective of the body politics. Many of the characters challenge what they consider to be obsolete notions and ideas. Nūrin, for instance, sweeps aside the east-west dichotomy; when his French friend and lover Emelda mentions Chahrazade, he retorts: "we have gone beyond the absurd duality of a mysterious and warm East deeply rooted in its spiritual allure, and a definite, reasonable, distant, and materialistic West." [19]

Likewise, the deep torment that Nabil Kader, Camelia's father, experiences vis-à-vis his Arab identity and his fascination with the "refinement" of French culture, is resolved through his daughter's alignment with an open notion of identity and her condemnation of her father's (and mother's) hypocrisy. Camelia does not only reconnect with the Arab and Amazigh components of Moroccan identity, but she also harshly criticizes her parents for being hypocritical and fake. Angry at them because of their insistence (especially her father's) to get rid of her fetus, Camelia tells them: "You are backward. You've long hidden behind catchwords like liberalism and fake modernity, but you're in reality as obnoxious as any worthless insect." [19] Thus, for Camelia, personal freedom goes hand in hand with the self-management of the body. This idea of the body is also invoked in relation with other characters, as mentioned earlier.

Through the character of 'Āslīn and her story, Sodom attempts to grapple with the Amazigh component of Moroccan identity in an attempt to uncover the forces that influence it. Throughout the novel, these forces seem to originate in authoritarianism. Thus, the story of the name to be given to 'Āslin at birth becomes the battling ground between the family and the local authorities. Led by Tareq, the family's elder son, an inveterate defender of Amazigh identity, the family contests the name of Aicha, given to 'Āslīn at birth. The father had wanted to give the name Tamālüt to the new-born baby, but it was refused on the grounds that it was against public common taste.

The two names are culturally charged. The mutual contestation of these two names reveals the range of the cultural opposition between Berberists and Arabists in Morocco. It constitutes only the tip of the iceberg. Sodom's narrative strategy visits other aspects of this political situation, namely the issue of whether the Arabs are to be seen as colonizers or not. This culturalist vision of the Amazigh identity paves the way for heated discussions among the seven characters of the novel. For instance, 'Āslinn, an actress who foregrounds the body as the battleground for emancipation and liberation, reenacts on stage the history of Morocco stressing the political and ideological supremacy of what she calls the "conquerors." According to her, "the body of woman was naked; it meant freedom, singing, dancing, and happiness. When the conquerors arrived, they covered and veiled it on a false excuse, namely that it was a temptation and it shocked the believers. But the main cause was the quelling of the idea of freedom, singing, and the desire to be happy." [19] 
This shows how 'Āslīn re-imagines history to make room for women's emancipation in a political context that lacks in freedom, according to her. However, 'Āslinn has no political claims other than freedom. When Mīlād asks her about the Amazigh movement, she says: "I don't believe that the Amazigh movement is a political cause. We aren't looking for a nation for the Amazigh. Nor are we trying to be politically independent from the State...It's a cultural issue in essence." [19] This revisionist stand suggests viewing the Amazigh language and Amazigh identity as an essential component of national identity by reaching back to the period preceding "Uqba's arrival" in Morocco [19]

The challenge of official history is also seen in terms of the opposition between high culture and folklore. The first is associated with classical Arabic poetry, while the second is reduced to different genres of Amazigh culture, like songs and dances. In a discussion of the issue of history, Mīlād says: "All the Amazigh complain about their falsified history. That's their right, but they haven't gone beyond this jeremiad." [19]

\section{Conclusions}

All of the three novels addressed here attempt to translate Morocco's cultural reality in quite different ways. In this article, this cultural reality has been approached as a "fond" that is at one and the same time shared and exclusive. In Numedia and Pike Fishing Season this "fond" is assimilated to Amazigh identity and space within the larger cultural space of Morocco. Numedia is more ambivalent and radical in its representation of Amazigh identity, since it frames it within the trope of the East-West encounter, while at the same time restaging Amazigh identity as a homogeneous component by symbolically granting Numedia the status of a woman-nation. However, this symbolic status is perceived solely through 'Awdad's dream. This makes reality in Numedia, (mostly Ighrem as a space) seem like an ungraspable dimension that is later dissolved into a dream. In Pike Fishing Season, however, the obverse seems to take place, since fantasy is dissolved into reality. Both novels reach for a final effect. In Numedia, 'Awdād dies and Numedia disappears, while in Pike Fishing Season the Franco-Moroccan narrator is able to locate his mother's grave and reunite with his family. Conversely, there is no resolution in Sodom, unless it be the perpetuation of the sense of an ongoing negotiation between the different modalities of Moroccan identity. Even the central idea which the novel attempts to foreground as a possible outlet from the politics of oppression remains unstressed. Sodom seems to complicate the sense of belonging as well as the sense of Moroccanness by highlighting the conflicting notions associated with other ways of belonging (Jews, for instance). In this perspective, unlike Numedia and Pike Fishing Season, which seem to celebrate a comfortable, almost exclusivist sense of belonging, Sodom obfuscates any facile and comfortable sense of identity.

\section{References}

[1] Gerhard Neumann, Kafka-Lektüren, Berlin/Boston, Walter de Gruyter, 2013.

[2] Kīlītu, 'Abdilfattāḥ (Kilito Abdelfettah), Atakallamu jamī'a al-lughāt, lākin bi al-`arabiyya” (I speak all languages, but in Arabic). Trans. 'Abdusalām Bin`abdil'ālī. (Casablanca: Dār Tubqāl, 2013).

[3] Qtd in Bruce Maddy-Weitzman, The Berber Identity Movement and the Challenge to North African States, Austin, University of Texas Press, 2011.

[4] Octavio Paz, Translation: Literature and Letters, in: Theories of Translation: An Anthology of Essays from Dryden to Derrida (ed.), Rainer Schulte and John Biguenet, Chicago, University of Chicago Press, 1992, pp. 152-162.

[5] Gilles Deleuze, Difference and Repetition, Trans. Paul Patton, New York, Columbia University Press, 1994.

[6] Joe Hughes, Deleuze's Difference and Repetition: A Reader's Guide, London and New York, Continuum, 2009. 
[7] Albert Memmi, Portrait du colonisé et du colonisateur. Préface de Jean-Paul Sartre, Paris, Petite Bibliothèque Payot, 1973.

[8] Abdelkébir Khatibi, Le roman maghrébin, Rabat, SMER, 1979.

[9] Fouad Laroui, Le drame linguistique marocain, Zellige, Léchelle, France, 2011.

[10] Gonzalo Fernández Parrilla, La literatura marroquí contemporánea, Ediciones de la Universidad de Castilla, La Mancha, Spain, 2006.

[11] Kamal Abu-Deeb, The Collapse of Totalizing Discourse and the Rise of Minority/Marginalized Discourses, in: Tradition, Modernity, and Postmodernity: Essays in Honour of Professor Issa J. Boullata (ed.), Kamal Abdel-Malek, Wael Hallaq, Brill, Leiden, 2000, pp. 335-366.

[12] Roger Allen, The Arabic Novel: an Historical and Critical Introduction, Syracuse University Press, Syracuse and New York, 1982.

[13] Gonzalo Fernández Parrilla, Breaking the Canon: Zafzaf, Laroui and the Moroccan Novel, in: Stephan Guth, Gail Ramsay (ed.), From New Values to New Aesthetics: Turning Points in Modern Arabic Literature, Harrassowitz Verlag, Wiesbaden, 2011, pp. 75-84.

[14] Samah Selim, The Narrative Craft: Realism and Fiction in the Arabic Canon, Edebiyât: The Journal of Middle Eastern Literatures. 14(1-2) (2003) 109-28.

[15] G.F. Parrilla, Breaking the Canon: Zafzaf, Laroui and the Moroccan Novel, From New Values to New Aesthetics. Turning Points in Modern Arabic Literature. 2. Postmodernism and Thereafter. (2011) 75-85.

[16] Magda M. Al-Nowaihi, Committed Postmodernity: Muhammad Barrada's The Game of Forgetting, in: Tradition, Modernity, and Postmodernity: Essays in Honour of Professor Issa J. Boullata (ed.), Kamal Abdel-Malek, Wael Hallaq, Brill, Leiden, 2000, pp. 367-388.

[17] Țāriq Bakkārī, Numedia (Numedia), Dār al-'ādāb, Beirut, 2015.

[18] 'Ismā̄îl Ghazālī, Mawsim sayd az-zanjūr (Pike fishing season), Dār al- 'ayn, Cairo, Egypt, 2014.

[19] 'A Abdalḥamīd Shawqīi, Sadūm (Sodom), Dār al-'ādāb, Beirut, Lebanon, 2015.

[20] Amina El Messaoudi, Les ministres de Hassan II, in: Anciennes et nouvelles élites du Maghreb, Actes du colloque Zarzis III, ed. Nourredine Sraïeb, Amina El Messaoudi, Edisud, Ex-en-Provence, France, 2003, pp. 139-48.

[21] Rasheed El-Enany, Arab Representations of the Occident: East-West Encounters in Arabic Fiction, Routledge, London and New York, 2006.

[22] Beth Baron, Egypt as a Woman: Nationalism, Gender, and Politics, University of California Press, Berkley, 2005.

[23] Ernest Renan, What is a Nation, Trans. Martin Thom, in: Nation and Narration (ed.), Homi Bhabha, Routledge, London and New York, 1990, pp. 8-22.

[24] Jacques Rancière, Slavoj Zizek, The Politics of Aesthetics, Trans. Gabriel Rockhill, Continuum, New York, 2004. 